\title{
LEFT OR RIGHT, UP OR DOWN: A CASE FOR POSITIONING OF UNCONCIOUS HEAD-INJURED PATIENTS
}

\author{
Margot Hugo
}

\section{Abstract}

Nursing care activities have been proved to cause increases in intracranial pressure (ICP) which could be detrimental to the patient's health. Because positioning is one of the activities that causes the greatest pressure changes it was evaluated in this study. Cumulative increases also occur when nursing care activities are carried out in quick succession. The analysis of the data and literature suggest that the backrest position with the head of the bed evlevated 30 to 45 degrees is the best position for $a$ patient with increased ICP. If further research should prove that this position has a negative influence on the cerebral perfusion pressure, these recommendations will have to be revised.

\section{Op.somming}

Daar bestaan bewyse dat verpleegsorghandelinge ' $n$ toename in intrakraniale druk (IKD) tot gevolg kan hê wat 'n nadelige effek op die pasiënt se gesondheid uitoefen. Aangesien posisionering een van die aktiwiteite is wat die grootste drukveranderinge tot gevolg het was dit in die ondersoek geëleveer. Kumulatiewe drukstygings ontstaan wanneer verpleegsorghandelinge vinnig op mekaar volg. By die ontleding van die data sowel as die literatuur blyk dit dat die rugliggende posisie met die koppenent van die bcd tussen 30 tot 45 grade geëvalueer die beste posisie vir die pasiënt met verhoogde IKD is. Indien dit sou blyk dat die serebrale perfusie druk negatief beïnvloed word deur hierdie pesisie moet hierdie aanbevelings egter hersien word.

\section{INTRODUCTION}

Nursing care activities have been proved to cause increases in intracranial pressure (ICP) which could be detrimental to the patient's health. During the past decade studies have appeared in the literature suggesting the negative or positive effects of various positions or nursing actions. In most textbooks on the nursing care of head injured patients it is suggested that the head of the bed be elevated between 30 to 45 degrees unless symptoms of shock are present (Sherry, 1982:31; Marshall \& Bowers, 1982:314; Davenport-Fortune \& Dunnum, 1985:368; Viquesney, 1987:47). However, none of these authors take cerebral perfusion pressure into account. Could it be possible that although the ICP is being treated by the 'head up' position the effects on cercbral perfusion pressure (CPP) could in itself cause harm to the patient? Is it possible to give the correct nursing care to patients who have suffered severe head injuries without proper monitoring of the relevant haemodynamic parameters? As we are all aware, nothing can be done to reverse the primary brain injury, but it is important that evcryone should try to limit secondary brain injury which is of ten worse than the primary injury. Due to fear of aggravating the injury nurses tend to keep 'hands off' so that no harm can be done. This does not mean it is the best option. Mcticulous nursing care still forms the basis for quality nursing care which is essential for the patient's wellbeing.

One of the main factors associated with changes in ICP is the positioning of the patient. Patients need to be positioned in the best possible way without causing too much of an increase in ICP The purpose of this study was to establish the best position for nursing of head-injured patients, as well as the best way to schedule repositioning in order to cause the least increase in pressure.

ICP will be described briefly to clarify the rest of the article.

\section{INTRACRANIAL PRESSURE (ICP)}

In 1977 the Richmond group examined 225 seriously brain injured patients and monitored their ICP. They found that $70 \%$ of the patients with brain lesions requiring surgery had increased ICP and that $30 \%$ of the group died as a result of the increased pressure. In patients with diffuse brain injury $33 \%$ had increased pressure, of whom four percent were uncontrolled. In the case of intracerebral contusions $70 \%$ of the patients had increased pressure, six percent of whom were uncontrolled. Of the patients who underwent surgery $50 \%$ continued to have problems with increased ICP (Ward 1986:398). Bruce et al $(1981: 170-178)$ reported a $59 \%$ incidence of increased ICP in children with serious head injuries.

It appears that patients with increased ICP have a poorer prognosis. Whether this can be ascribed to the increased pressure per se or to the magnitude of the primary injury is difficult to determine (Jennett and Teasdale 1981:127; Ward 1986:398).

However, it is important to stress that the ultimate consequences of a head injury are a combination of the primary injury at the time of the impact and the secondary injury caused by the increased ICP and various other complications. This is why it is important to avoid or limit secondary injury as far as possible at all costs.

\section{PIIYSIOLOGY OF INTRACRANIAL PRESSURE}

Normal ICP usually varies between 0 and 10 $\mathrm{mmilg}\left(80-180 \mathrm{~mm} \mathrm{H_{2 }} 0\right)$. A pressure of more than $15 \mathrm{mmllg}$ is regarded as abnormal. The pressure oscillates during the respiratory and cardiac cycle, but these oscillations have no 
clinical significance (Hickey 1981:143; Nikas 1982:30).

The brain is accommodated in a closed container with inflexible walls. The skull is filled almost to capacity with the brain parenchyma which occupies approximately $86 \%$ of the total volume, while the CSF takes up about $9-10 \%$ and the total intracranial blood volume approximately 5-7\% (Jennett 1970:4). The ICP depends on a delicate balance between the brain tissue, CSF and intracranial blood volume. An increase in volume of any of the threc components must be at the expense of the others, otherwise the ICP rises. There are, however, compensatory mechanisms which can accommodate slight changes.

The theoretical volume-pressure curve gives an indication of the compliance or compensation that may be allowed. (See Figure 1). An initial increase in intracranial volume (ICV) does not cause a rise in ICP. A slight pressure increase docs, however, begin to occur at a certain level of unit volume increase (a). A considerable pressure increase occurs later, even if the unit of volume increase remains constant (b). The flat part of the pressure curve reflects the compliance of the brain where volumes can compensate and the pressure can be kept constant. The sharp rise in pressure reflects the decompensation phase in which slight increases in volume cause dramatic pressure increases (Nikas 1982:30).

The brain demands a constant blood flow to function effectively. Cerebral blood flow usually remains relatively constant and depends on cerebral perfusion pressure (CPP). CPP is the difference between the mean arterial pressure (MAP) and ICP (CPP = MAP - ICP) and varies between 80 and $100 \mathrm{mmllg}$ (Nikas 1982:54). CPP should not drop below $50 \mathrm{mmlig}$ since functional changes set in when it drops below 40-50 mmlig (Nikas 1982:33). A CPP of 30 $\mathrm{mmHg}$ is incompatible with life and leads to neural hypoxia and cell death (Hickey 1981:144).

The interaction hetween CPP and ICP is very complex. A rise in ICP can, for instance, cause a drop in CPP, while a primary increase in CPP as a result of vasodilatation, can cause a rise in ICP. A critical point is reached when the ICP is within $40 \mathrm{mml}$ Ig of MAP because cercbral blood now diminishes as the CPP declines (Jennett 1981:55).

An analysis of findings reported in the literature will be given to determine the influence of positioning on ICP.

\section{META-ANALYSIS OF TIIE LITERATURE}

Mitchell (1980:150) found that very little systematic research had been done on ICP and the factors that influence it. Although there are a number of anecdotal reports on specific incidents, qualitative and quantitative pressure increases and stimuli frequencies are seldom found in the literature. A number of researchers have published anecdotal reports on ispects that influence ICP since l.undberg ( 1960:193) found that physical activitics and emotional outbursts lead to plateau increases. The relationship between head rotation and positioning and ICP has often been studied but never quantified.

One of the first systematic research reports on nursing care activities and ICP appeared in 1977. Shalit and Umansky reported on pressure changes that occur during positioning. In this case, 10o, the duration and quality of the increases were not investigated (Shalit and Umansky, 1977:881-886).

Figure 1

Theoretical volume-pressure curve.

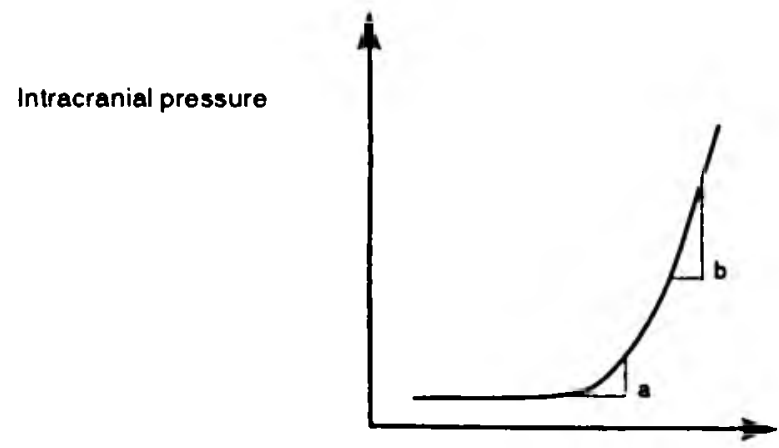

Intracranial volume
In 1978 Mitchell and Mauss (1978:4-10) studied factors that influence ICP. They used CSF drainage through a ventricle catheter as an index of ICP and, therefore could not also measure the quality of the increases. They found that activities such as repositioning were almost always associated with CSF drainage, while passive movement almost never led to CSF drainage unless it occurred simultaneousiy with the former activities (Mitchell, 1980:150).

Mitchell et al. (1980:565-568) conducted a further study in 1980 about aspects such as passive movement, tuming and head rotation and ICP. They found that the pressure rose after a change of position in 88 percent of cases and that the duration of the increase was 5 minutes. A further finding was that activities performed at 15 minute intervals resulted in a cumulative pressure increase, but that that this did not occur if an hour elapsed between repositionings. Head rotation also led to pressure increases (Mitchell, 1980:150,151).

Weed demonstrated as early as 1929 that ventricular fluid pressure in dogs dropped with elevation of the head and rose when the head was lowered. Nornes and Magnaes found in 1971 that neck flexion, hip flexion, the supine position and 90 degrees head rotation consistently resulted in increased ICP. This corresponds with studies by Hulme and Cooper (1977) and Shalit and Umansky (1977). Lipe and Mitchell (1980) believe that an elevaled ICP is caused by a drop in venous outflow, Valsalva's manoeuvre and obstruction of CSF outflow from the basal cisterns (Goldberg et al., 1983:428-439; Mitchell, 1980:151; Mitchell, Ozuna and Lipe, 1981:213).

Parsons and Wilson studied changes of position. In 200 observations they found that all position changes, with the exception of elevation of the head, were accompanied by an increase in heart rate, mean arterial blood pressure, mean ICP and cerebral perfusion pressure (1984:68-75). These findings concur with those of a study by Boortz-Marx (1985:89-94).

Maximum increases in ICP were observed by Hulme and Cooper (1976:259) during neck flexion, bilateral jugular vein obstruction and head rotation to the right if the baseline pressure was above $10 \mathrm{mml}$ Ig. This may indicate that this group of patients had high brain clastance and that they were, therefore, more susceptible to venous outflow obstruction and volume increase.

Lipe and Mitchell (1980:1036) found that the left latcral position resulted in greater pressure increases than the right lateral position. This tendency is ascribed to anatomical differences. The left internal jugular vein is often anatomically smaller than its right counterpart, thus increasing its risk for potential obstruction. liurthermore, the left internal jugular vein joins the left subclavian vein at right angles to form the brachiocephalic vein, while the right 
junction forms a blunt angle (Romanes, 1964:919). The findings of Lipe and Mitchell correspond with those of Hulme and Cooper, that is, that rotation to the right, especially at an angle of 90 degrees, causes greater pressure increases, particularly if the baseline pressure is above $10 \mathrm{mmHg}$.

Fuller (1982:60,61) observes that Parsons used a soft cervical neck brace as a protective measure for patients with a tendency to ICP increases during positioning, with very positive effects.

Mitchell recommends that nursing care measures be planned with great care for patients with an elevated ICP, high elastance and who have exhibited pressure increases after previous actions, as any further actions are sure to cause pressure increases. She particularly advises a conservative approach to patients whose pressure is not monitored, but who run a high risk of intracranial hypertension, since clinical signs are not a reliable and sensitive reflection of ICP. The left lateral position should be used with the utmost caution. The advantages and disadvantages of head rotation during bronchial toilet should be carefully weighed especially in view of the fact that this rotation causes pressure increases (Lipe and Mitchell, 1980:1036; Mitchell, 1980:151-153); (Mitchell et al., 1981:218).

Another aspect investigated was the influence of rest on ICP. Mitchell (1980:150) observed cumulative pressure increases when procedures were conducted at 15 minute intervals. Bruya conducted a similar study in which she allowed 10 minute rest periods before every procedure. She also found that a ten minute period of complete rest made no difference and that pressures continued to rise cumulatively (1981:184-194). Mitchell, on the other hand, found a significant difference if patients rested for at least an hour because the pressure had sufficient time to return to the baseline (1980:217). Although it is often difficult to allow patients in critical care units to rest for an hour, these findings stress the fact that careful nursing care planning can contribute to better control of ICP (Mitchell, 1980:153).

Shalit and Umansky (1977:886) even go as far as to claim "that the cumulative effect of increases in intracranial pressure which take place during routine management of these patients may be a major factor in determining the outcome of the illness".

Researchers could find no statistically significant effect on oxygen saturation and heart rate when they studied the influence of repositioning and lateral and supine positions with the head of the bed elevated at an angle of 20 or 40 degrees (Noll and Fountain, 1990:243-251; Shively, 1988:51-59; Clark, Winslow, Tyler and White, 1990:557-561). Winslow et al. reported transient increases in heart rate and a decrease in mixed venous

Table 1

Influence of specific body positions on ICP: Mete-analyses of literature.

\begin{tabular}{|c|c|c|c|}
\hline AUTHOR & $\begin{array}{l}\text { NUMBER OF } \\
\text { SUBJECT }\end{array}$ & BODY POSTTIONS & EFFECT ON ICP \\
\hline Weed (1929) & 39 dogs & $\begin{array}{l}\text { head up } \\
\text { head down }\end{array}$ & $\begin{array}{l}\text { down } \\
\text { up }\end{array}$ \\
\hline $\begin{array}{l}\text { Nomes \& Magnaes } \\
\text { (1971) }\end{array}$ & 14 patients & $\begin{array}{l}\text { sitting (neck and hip } \\
\text { flexion) } \\
\text { prone }\end{array}$ & up \\
\hline $\begin{array}{l}\text { Hulme \& Cooper } \\
\text { (1976) }\end{array}$ & 18 patients & $\begin{array}{l}\text { neck flexion } \\
\text { head rotation } \\
\text { bilateral jugular } \\
\text { compression }\end{array}$ & up \\
\hline $\begin{array}{l}\text { Shalit \& Umansky } \\
\text { (1977) }\end{array}$ & 21 patients & $\begin{array}{l}\text { tuming } \\
\text { head rotation }\end{array}$ & $\begin{array}{l}\text { up or down } \\
\text { up }\end{array}$ \\
\hline Magnaes (1978) & 4 patients & $\begin{array}{l}\text { sitting } \\
\text { return to lying }\end{array}$ & $\begin{array}{l}\text { down } \\
\text { up }\end{array}$ \\
\hline $\begin{array}{l}\text { Mitchell \& Mauss } \\
\text { (1978) }\end{array}$ & 9 patients & turning & up \\
\hline Mitchell et al (1981) & 18 patients & $\begin{array}{l}\text { tuming } \\
\text { head rotation }\end{array}$ & $\begin{array}{l}\text { up or down } \\
\text { up }\end{array}$ \\
\hline Snyder(1983) & 9 patients & turning & up \\
\hline $\begin{array}{l}\text { Parsons \& Wilson } \\
\text { (1983) }\end{array}$ & 18 patients & $\begin{array}{l}\text { turning } \\
\text { head up } \\
\text { head down }\end{array}$ & $\begin{array}{l}\text { up } \\
\text { down } \\
\text { up }\end{array}$ \\
\hline Goldberg et al (1983) & 26 patients & $\begin{array}{l}\text { head up } \\
\text { head down } \\
\text { tuming }\end{array}$ & $\begin{array}{l}\text { down } \\
\text { up } \\
\text { up }\end{array}$ \\
\hline Boortz-Marx (1985) & 4 patients & $\begin{array}{l}\text { head rotation } \\
\text { turning } \\
\text { head up }\end{array}$ & $\begin{array}{l}\text { up } \\
\text { up } \\
\text { down }\end{array}$ \\
\hline Hugo (1988) & 23 patients & $\begin{array}{l}\text { head up } \\
\text { head down } \\
\text { turning } \\
\text { head rotation }\end{array}$ & $\begin{array}{l}\text { down } \\
\text { up } \\
\text { up } \\
\text { up }\end{array}$ \\
\hline Lee (1989) & 30 patients & $\begin{array}{l}\text { head up } \\
\text { head down } \\
\text { head rotation }\end{array}$ & $\begin{array}{l}\text { down } \\
\text { up } \\
\text { up }\end{array}$ \\
\hline March ef al (1990) & 4 patients & $\begin{array}{l}\text { flat backrest } \\
\text { head up }\end{array}$ & $\begin{array}{l}\text { up or down } \\
\text { up or down }\end{array}$ \\
\hline
\end{tabular}

oxygen saturation which gradually returned to baseline levels during the following four minutes. They state that should turning trigger large or prolonged changes in mixed venous oxygen saturation or heart rate, prompt repositioning and evaluation are needed to prevent adverse effects.

It scems that neither repositioning nor possibly either of the lateral positions have a significant influence on any of the other haemodynamic parameters, but these should nevertheless be carefully applied to patients with elevated ICP (see Table 1).

March et al. (1990:375-381) found that cerebral perfusion pressure is lowered in some patients by elevating the head of the bed, even though it has a positive effect on the ICP. Although the findings did not occur consistently in all patients, it may be a factor which demands further research.

\section{METHOD AND DESIGN}

A descriptive, non-participant,empirical observational study was undertaken in a neuro-surgical intensive care unit (N-ICU) to establish the effect of positioning on the ICP of severely head- injured patients. A head injured patient with a coma scale count of eight or less, loss of consciousness of longer than six hours and/or an abnormal computer tomographic scan is regarded as seriously head-injured (Jennet et al. 1977:292). In the selected research unit measuring the ICP by means of an epidural pressure monitor or a ventricular catheter was standard protocol. 
The field work of the study was conducied over a six month period and included twenty-three patients admitted to the selected $\mathrm{N}-\mathrm{ICU}$, who satisfied the following criteria:

- Severe head injury

- Glasgow Coma Scale score of 8 or less

- Unconscious for longer than six hours after the impact injury

- Abnormal CT-scan

* Signs of increased ICP

* No hypoxic injuries

* ICP monitoring with an cpidural transducer for not less than rwelve hours.

Patients whose ICP was monitored for less than a 12 hour period were omitted from the study. However, the initial twelve hours were part of the 72 hour study monitoring period. The variables studied were positioning and repositioning of the patient in the left lateral, right lateral, supine, and head of bed elevated 0 , 15,30 or 45 degrees and their effect on the ICP. The various factors that influence ICP will be discussed in further articles. However, all the patients were intubated and mechanically ventilated as part of the treatment protocol for elevated ICP.

As a non-participant observer the researcher did all the observations and monitoring of the patients over a 72 hour period following admission to the $\mathrm{N}-\mathrm{ICU}$.

\section{DA'TA-ANALYSIS}

The patients' positions were changed every two to four hours. Conventional hospital beds, the heads of which can be turned up were used in the research unit. Whenever possible patients were turned by at least two nurses standing on either side of the bed. The log rolling method was followed throughout to turn the patients onto alternate sides. The various treatment regimes and other variables were taken into account. Each patient's mean ICP, mean pressure increase (maximum ICP minus mean ICP) and the duration of the pressure increase was measured during the 72-hour period. Three hundred and sixty-nine events of positional changes were observed. The mean base-linc ICP was $13,48 \mathrm{mmHg}$, the mcan pressure increase $15,70 \mathrm{mmlig}$ and the duration of increase 6,34 minutes. This means that the mean peak pressure obtained was $29,18 \mathrm{mmHg}$. (Peak pressure refers to the highest ICP occurring during a nursing intervention and is synonymous with maximum pressurc, but is used to prevent confusion between maximum pressure and maximum pressure increase.) The maximum pressurc increase observed was 39,18 mmlig which means the peak pressure could have been as high as $52,66 \mathrm{mml}$. These are dangerous increases in the alrcady compromised patient and should he avoided (See Table 2.)

The data were subjected to the Fisher-exact-test in order to determine the relationship between the mean pressure and the duration of the pressure increase. A distinction was made between pressures of more and less than 15 $\mathrm{mmH}$, and between a duration of increase of more and less than 10 minutes. Possibly due to the sample size, no statistically significant difference could be demonstrated. This test was done to determine whether patients with increased ICP ( $\mathrm{mmH} / \mathrm{g}$ ) are more apt to plateau increases $(10 \mathrm{~min})$. The findings from the available data secm tosuggest that patients with increased ICP are more apt to plateau increases while those with pressures within normal limits are more likely to have peak increases (see Table 3)

Repositioning is usually done during or after a bedbath or back care. This could cause a cumulative increase and duration of increase, which could have a detrimental effect on the patient's ICP, as reported by Mitchell (1980:150).

Most of the patients werc positioned with the head of the bed clevated 45 degrees. Patients were repositioned every two to four hours by changing their positions to backrest, left or right

Table 2

Mean Pressure Increase and Duration of Increase associated with Repositioning

\begin{tabular}{|c|c|c|c|c|}
\hline Observations & $\begin{array}{c}\text { Meen baseline } \\
\text { ICP }\end{array}$ & $\begin{array}{c}\text { Mean pressure } \\
\text { increase }(\mathbf{m m H g})\end{array}$ & $\begin{array}{c}\text { Mean peak } \\
\text { pressure }(\mathbf{m m H g})\end{array}$ & $\begin{array}{c}\text { Mean duration of } \\
\text { increase (min.) }\end{array}$ \\
\hline 369 & 13,48 & 15,70 & 29,18 & 6,34 \\
\hline
\end{tabular}

Table 3

Relationship between mean ICP and duration of pressure increase.

\begin{tabular}{|c|c|c|c|}
\hline \multicolumn{4}{|c|}{ FISHER-EXACT-TEST } \\
\hline Action & Duration (minutes) & \multicolumn{2}{|c|}{ Mean ICP (mmHg) } \\
\hline & & $\leq 15 \mathrm{mmHg}$ & $215 \mathrm{mmHg}$ \\
\hline Repositioning & $\leq 10$ & $18(90 \%)$ & 2 \\
& $>10$ & 1 & $2(67 \%)$ \\
\hline
\end{tabular}

Table 4

Mean Baseline Pressure Difference assoclated with Repositioning

\begin{tabular}{|l|c|c|c|}
\hline \multicolumn{1}{|c|}{ POSITIONAL ChANGE } & $\begin{array}{c}\text { MEAN BASELINE } \\
\text { PRESSURE } \\
\text { DIFFERENCE }\end{array}$ & MIN & MAX \\
\hline 1. Lett lateral to back & $-0,53$ & $-7,71$ & 11,00 \\
\hline 2. Back to left lateral & 2,38 & $-2,00$ & 16,00 \\
\hline 3. Pight lateral to back & $-0,72$ & $-12,00$ & 5,50 \\
\hline 4. Back to right lateral & 0,53 & $-3,00$ & 5,00 \\
\hline 5. Left lateral to right lateral & $-1,21$ & $-8,50$ & 3,00 \\
\hline 6. Plight lateral to left lateral & 1,11 & 0,00 & 3,33 \\
\hline
\end{tabular}




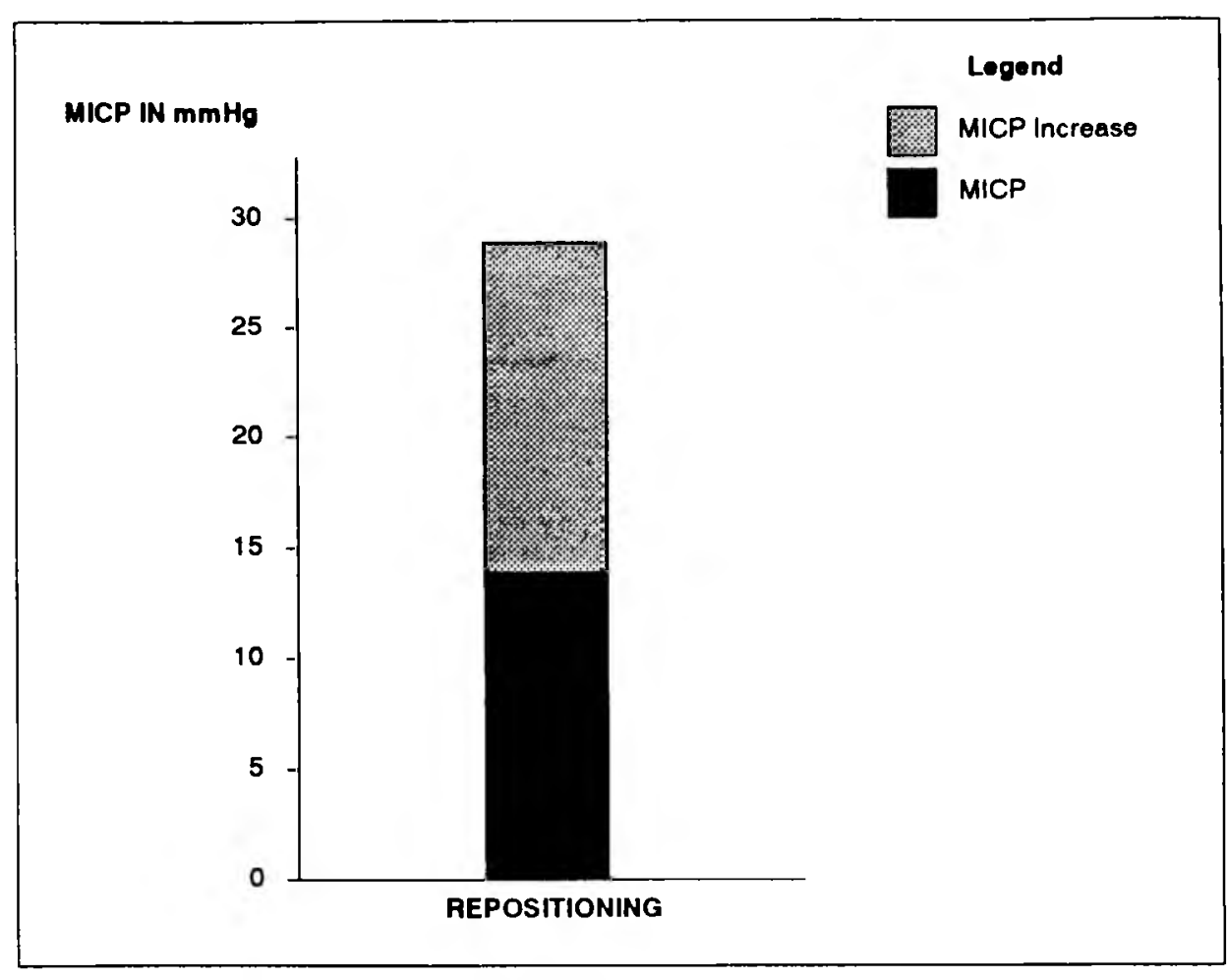

FIGURE 2 (a)

Mean ICP increase associated with Repositioning

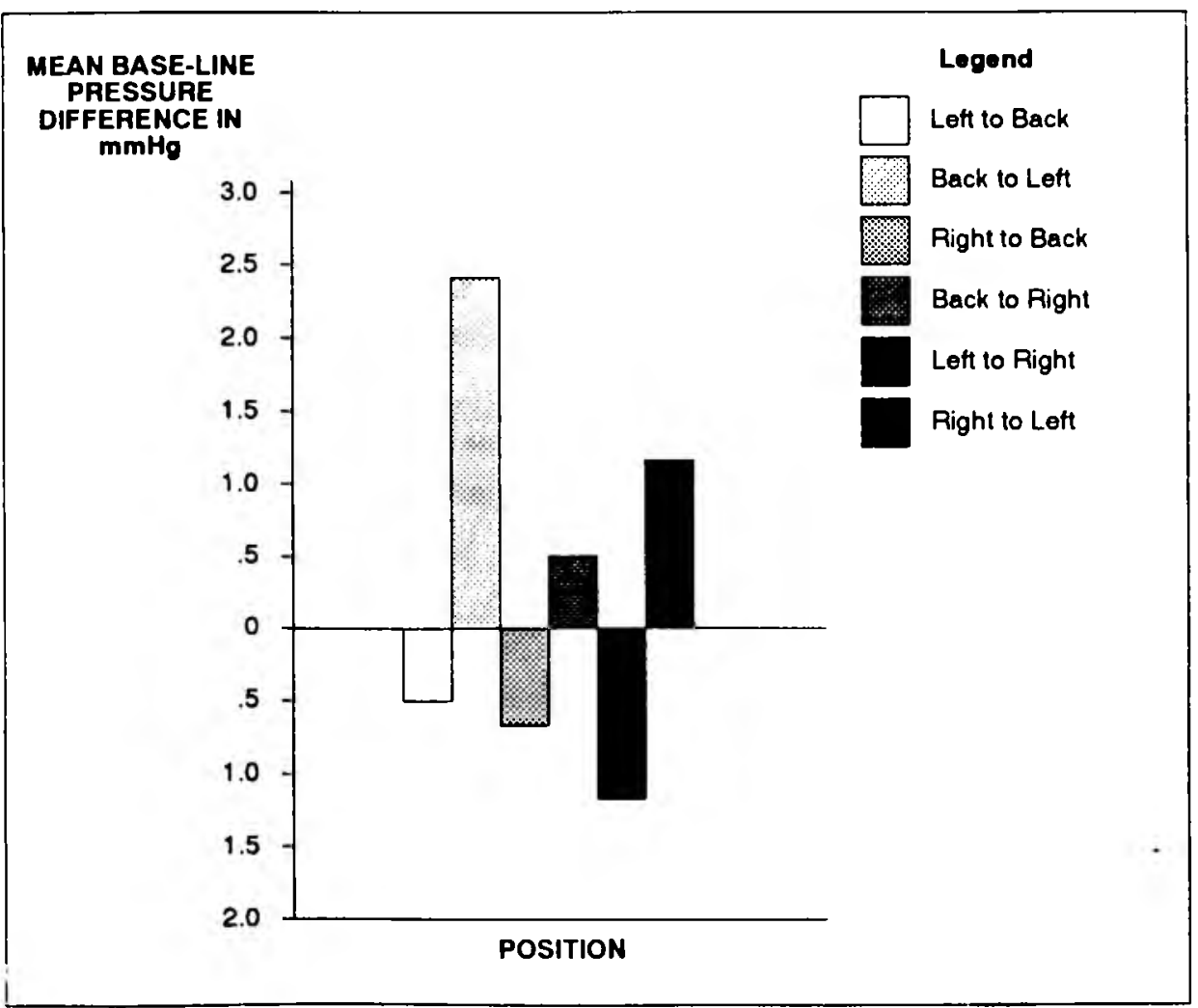

FIGURE 2 (b)

Mean Base-line Pressure Difference associated with Repositioning

significant correlation was established ( $p 0,05)$. When the mean for ICP-increase, duration of increase and frequency of activities were calculated, a significant correlation between duration and frequency could be established ( $p$ $=0,04$ ), but it could not be established for mean ICP-increase and duration of increase $(p=0,55)$. A larger sample might have produced different results.
A statistically significant difference was established with the Mann-Whitncy-test where two or fewer activities occurred in one hour and those in which more than two occurred when compared to the duration of increase $(p=0,007)$.

Careful planning of nursing care activities is therefore, of the utmost importance to ensure quality nursing care with the least negalive influence on the ICP of head injured patients.

\section{CONCLUSIONS}

The repositioning of severely head-injured patients should be planned carefully in order to limit pressure increases to the minimum. Individual patients' pressures should be analyzed to establish sensitivity with regard to brain elastance. Positions that are not well tolerated by a particular patient should be avoided or if unavoidable allowed for only a very brief period.

In summary, the data show:

- Best position :

Supine with head of bed elevated between $30-45$ degrees

- Best positional changes left lateral to right lateral left lateral to back right lateral to back

* Worst position : left lateral head of bed not elevated

- Worst positional changes : back to left lateral back to right lateral right lateral to left lateral

The data obtained from the research and literature shows that the ICP of patients with severe head injuries should be monitored in order to evaluate and apply specific treatment modalities. Monitoring the ICP is important to nurses as it provides valuable information for optimum nursing care planning.

The scheduling of nursing interventions forms the basis of planning. If the patient has high brain elastance and is inclined to frequent peak and plateau increases, unnecessary nursing actions should be scheduled at longer intervals.

Nursing interventions that have a negative influence on the ICP should not be performed together or successively. Since a bedbath, repositioning, bronchial toilet and mouth toilct often cause significant ICP elevation, these procedures should be carefully scheduled and should not all be performed in quick succession as this will have a cumulative effect on the ICP. It is important to record the particular positions or nursing actions to which the patient is most sensitive, in order that all the members of the health team may consider them when performing procedures. Although the best position recommended at present is one in which the head of the bed is elevated at an angle of 30-45 degrees, future research may yet prove the contrary.

Monitoring the ICP does not depend only on the observation of an average baseline pressure. It is absolutely essential that nurses evaluate the 


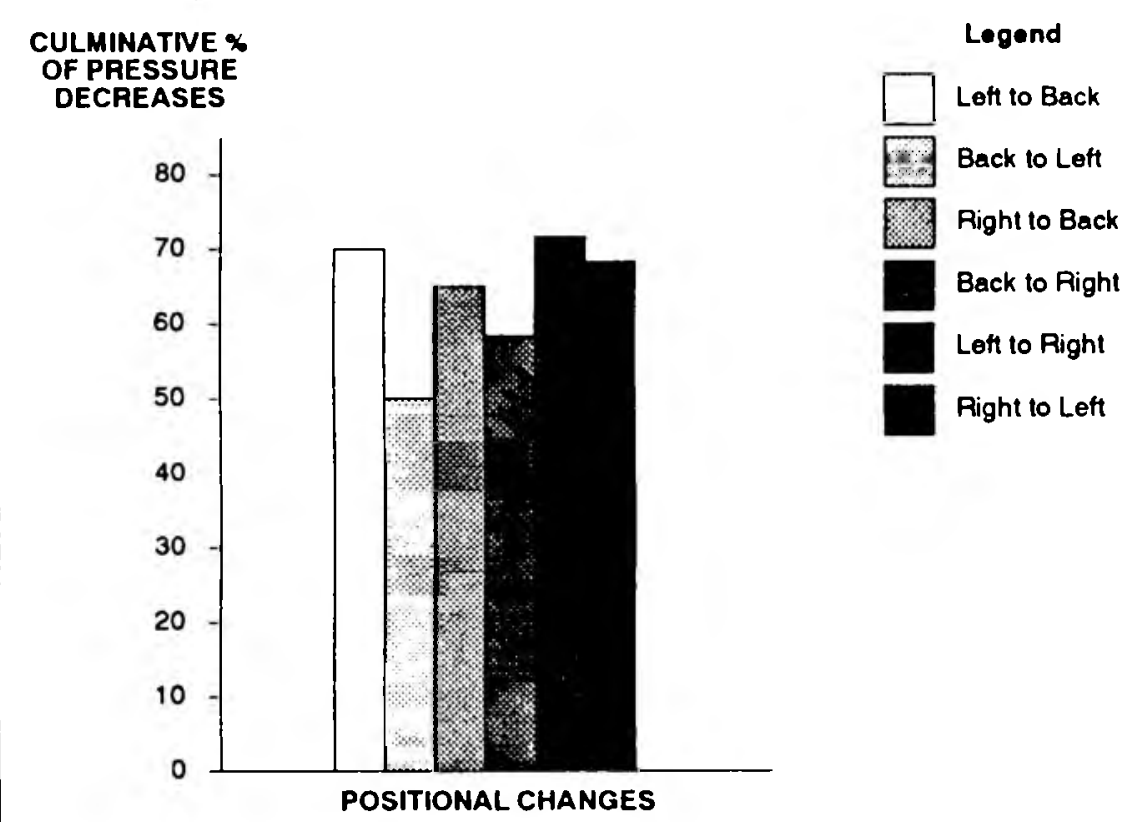

FIGURE 2 (c)

Base-line Pressure Differences assoclated with Positional Changes

quality and quantity of ICP increases. This allows them to form an impression of the degree of compliance of the patient's brain in order that they may plan the treatment protocol accordingly. The most important aspect, and this cannot be sufficiently stressed, is that the scheduling of patient care is determined by the patient and not by the nurse.

\section{BIBLIOGRAPIIY}

BOORTZ-MARX R., 1985: Factors affecting Intracranial Pressure: a descriptive study. Journal of Neurosurgical Nursing, 17(2):89-94.

BRUCE D.A., ALAVI A. AND BIBLANIUK L. et al, 1981: Diffuse cerebral swelling following head injuries in children: the syndrome of malignant brain edema. Journal of Neurosurgery, 54:170-178.

BRUYA M.A., 1981: Planned periods of rest in the intensive care unit: Nursing care activities and intracranial pressure. Journal of Neurosurgical Nursing, 13(4): 184-194

DAVENPORT-FORTUNE P. AND DUNNUM L.R., 1985: Professional nursing care of the patient with increased intracranial pressure: Planned or 'Hit and Miss'? Journal of Neurosurgical Nursing, 17(6):367-370.

FULLER E., 1982: Sclecting a clinical nursing problem for research. Image, $14: 60-61$.

GOLDBERG R.N., JOSIII A., MOSCOSO P. AND CASTILLO T., 1983: The effect of head position on intracranial pressure in the neonate. Critical Care Medicine, $11(6): 428-430$.
HICKEY J., 1981: The clinical practice of neurological and neurosurgical nursing. Philadelphia: J.B. Lippencott.

HUGO M.J., 1988: Die effek van verpleegsorghandelinge op die intrakraniale druk van die hoofbeseerde pasient. D.Soc.Sc.-proefskrif. Universitcit van dic Oranje-Vrystaat. Ongepubliseerde werk.

HULME A. AND COOPER R., 1976: The effects of head position and jugular vein compression on intracranial pressure. In: Intracranial Pressure III. Edit. J.W. Beks et al., New York: Springer-Verlag :259-263.

JENNETT B. AND TEASDALE G., 1981 Management of head injuries. Piladelphia: F.A. Davis.

JENNETT B., TEASDALE G. AND GALBRAITH S. ET AL, 1977: Severe head injuries in three countries. Journal of Neurology, Neurosurgery and Psychiatry, $40(3): 291-298$.

JENNETT W.B., 1970: An introduction to Neurosurgery. Second edition. London: Williams Heinemannn Medical Books.

LEE S-T., 1989: Intractanial pressure changes during positioning of patients with severe head injury. Heart \& Lung, 18(4):411-414.

LIPE H.P. AND MITCHELL P.H., 1980: Positioning the patinet with intracranial hypertension: How turning and head rotation affect the internal jugular vein. Heart \& Lung, 9(6): 1031-1037.

L.UNDBBl:RG N., 1960: Continuous recording and control of ventricular fluid perssure in neurosurgical practice. Acta Psychiatry Scandinaıia, 36 (Suppl. 149)(1):193
MAGNAES B., 1976: Body Position and cerebrospinal fluid pressure, Part I: Clinical studies on the effect of rapid postural changes. Journal of Neurosurgery, 44: 687-697.

MARCH K., MITCHELL P., GRADY S. AND WINN R., 1990: Effect of backrest position on intracranial and cerebral perfusion pressures. Journal of Neuroscience Nursing, 22(6): 375-381.

MARSHALL L.F. AND BOWERS S.A., 1982: Medical management of head injury. Clincal Neurosurgery, 29: 312-325.

MITCHELL P.H. AND MAUSS N.K., 1978: Relations of patient-nurse activity to intracranial pressure variations: $A$ pilot study. Nursing Research, 27: 4-10.

MITCHELL P.H., 1980: Intracranial Hypertension: Implications of research for nursing care. Journal of Neurosurgical Nursing, 12(3): 14.5-154.

MITCHELL P.H., MAUSS N.K. AND OZUNA J., 1980: Relationship of nurse/patient activity and ICP variation. In: Intracranial Pressure $I V$. Edit: D. Shulman, et al. New York: Springer-Verlag: 565-568.

MITCHELL P.H., OZUNA J. AND LIPE H.P., 1981: Moving the patient in bed: Effects on intracranial pressure. Nursing Research, 30(4): 212-218.

NIKAS D.L., 1982: The critically ill neurosurgical patient. New York: Churchill Livingstone.

NOLL M.L. AND FOUNTAIN R.L., 1990: Effect of backrest position on mixed venous oxygen saturation in patients with mechanical ventilation after coronary artery bypass surgery. Heart \& Lung, 19(3): 243-251.

NORNES H. AND MAGNAES B., 1971: Supratentorial epidural pressure recorded during posterior fossa surgery. Journal of Neurosurgery, 35: 541-549.

PARSON L.C. AND WILSON M.M., 1984: Cerebrovascular status of severe closed head injured patients following passive position changes. Nursing Research, 3.3(2): 68-75.

ROMANES G.J., 1964: Cunningham's textbook of anatomy. London: Oxford University Press

SIIALIT M.N. AND UMANSKY F., 1977: Effect of routine bedside procedures on intracranial pressure. Israel Journal of Medical Science, 13: 881-886.

SHERRY D., 1982: Head Injuries: Your care counts. Journal of Practical Nursing, 32(4): 31-33.

SHIVELY M., 1988: Effect of position change on mixed venous oxygen saturation in coronary artery bypass surgery patients. Heart \& Lung, 17(1): 51-59. 
SNYDER M., 1983: Relation of nursing activities to increases in intracranial pressure. Journal of Advanced Nursing, 8: 273-279.

VIQUESNEY J.S., 1987: H.O.B. up or H.O.B. down? Nursing 87, 17(4) 47-49.

WARD J.D., MOULTON R.J., MUIZELAAR J.P. AND MARMAROU A., 1986: Cerebral homeostasis and protection. Unpublished work (In press).

WEED L.H., 1929: Experimental studies on intracranial pressure. Association for Research in Nenous and Menual Diseases, 8: 25-67.

WINSLOW E.H., CLARK A.P., WHITE K.M. AND TYLER D.O., 1990: Effects of lateral turn on mixed venous oxygen saturatio and heart rate in critcally ill adults. Heart \& Lung, 19(5): 557-561.

\section{Acknowledgements}

I would like to thank the Transvaal Provincial Administration for their consent which enabled me to conduct this research in one of their academic hospitals. The protocol for the research however, was approved by the Research Committees of the UOFS, as the research was part of a doctoral study undertaken at the University of the Orange Free State.

\section{Erkennings}

Ek wil graag my dank betuig aan die Transvaalse Provinsiale Administrasie vir die toestemming wat aan my verleen was om die navorsing in een van sy akademiese hospitale tc kon uitvoer. Die protokol vir die navorsing is egter deur die Navorsingskomitees van die UOVS goedgekeur en die navorsing was dan ook deel van 'n doktorale studie wat aan die Universiteit van die Oranje-Vrystaat onderneem was.

Margot Hugo (Professor, Department of Nursing University of the Orange Free State, D.Soc.Sc.) 